\title{
International Journal of
}

\section{Modern Education and Computer Science}

\section{Kol.5}

No.7 Sep. 2013

\section{IJMECS Kol.5}

Http:// www.mecs-press .org

Vol. 5 No.7 September 2013

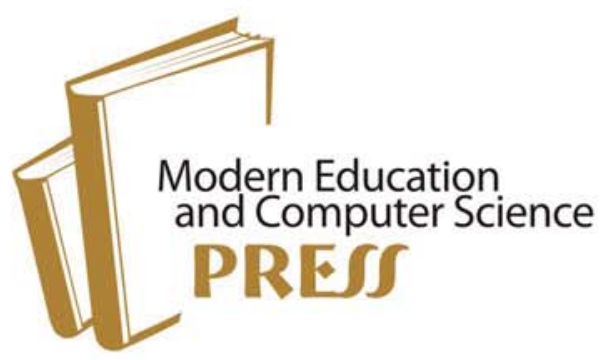




\section{Inte rnational Jo urnal of Mode rn Education and Computer Science (IJMECS)}

ISSN Print: 2075-0161, ISSN Online: 2075-017X

Volume 5, Number 7, September 2013

\section{Contents}

\section{REGULAR PAPERS}

Students' Understanding of Selected Aspects of Interface Class in Java

Ilana Lavy, Rami Rashkovits

Towards Qualitative Computer Science Education: Engendering Effective Teaching Methods

Basirat A. Adenowo, Stephen O. Adenle, Adetokunbo A.A. Adenowo

An Interactive Teaching - Learning Tool for Underprivileged Children in Rural Schools

H.Vignesh Ramamoorthy, P.J.Balakumaran, H.Karthikeyani

Evaluation: The New Philosophical Roles \& Psychological Means

Prashant M. Dolia

Spatial and Transform Domain Filtering Method for Image De-noising: A Review

Vandana Roy, ShailjaShukla

An Ingenious Wireless Home Security System and Protocol based upon Multi-hop 802.15.4 standard, Magnetic

contact and PIR sensor

Ulya Sabeel, Nidhi Chandra ,Shivraj Dagadi

Improving Teaching Methodology in System Analysis and Design using Problem Based Learning for ABET

Sara Fatima, Salha Abdullah

Economic Designing of PV/FC/Wind Hybrid System Considering Components Availability 